\title{
Antimicrobial nitric oxide releasing electrospun dressings for wound healing applications
}

Man Li $^{1}$, Jenny Aveyard ${ }^{1}$, Kyle Doherty ${ }^{2}$, Robert C. Deller ${ }^{1}$, Rachel L. Williams ${ }^{2}$, Keli N. Kolegraff ${ }^{3}$, Stephen B. Kaye ${ }^{2}$ and Raechelle A. D'Sa ${ }^{1,{ }^{*}}$

${ }^{1}$ School of Engineering, University of Liverpool, Liverpool, L69 3GH, United Kingdom

2 Department of Eye and Vision Science, Institute of Life Course and Medical Science, University of Liverpool, L7 8TX, United Kingdom

${ }^{3}$ Department of Plastic and Reconstructive Surgery, The Johns Hopkins University School of Medicine, 601 North Caroline Street, Baltimore, Maryland 21287, United States

${ }^{*}$ Corresponding Author: r.dsa@liverpool.ac.uk

SUPPORTING INFORMATION 

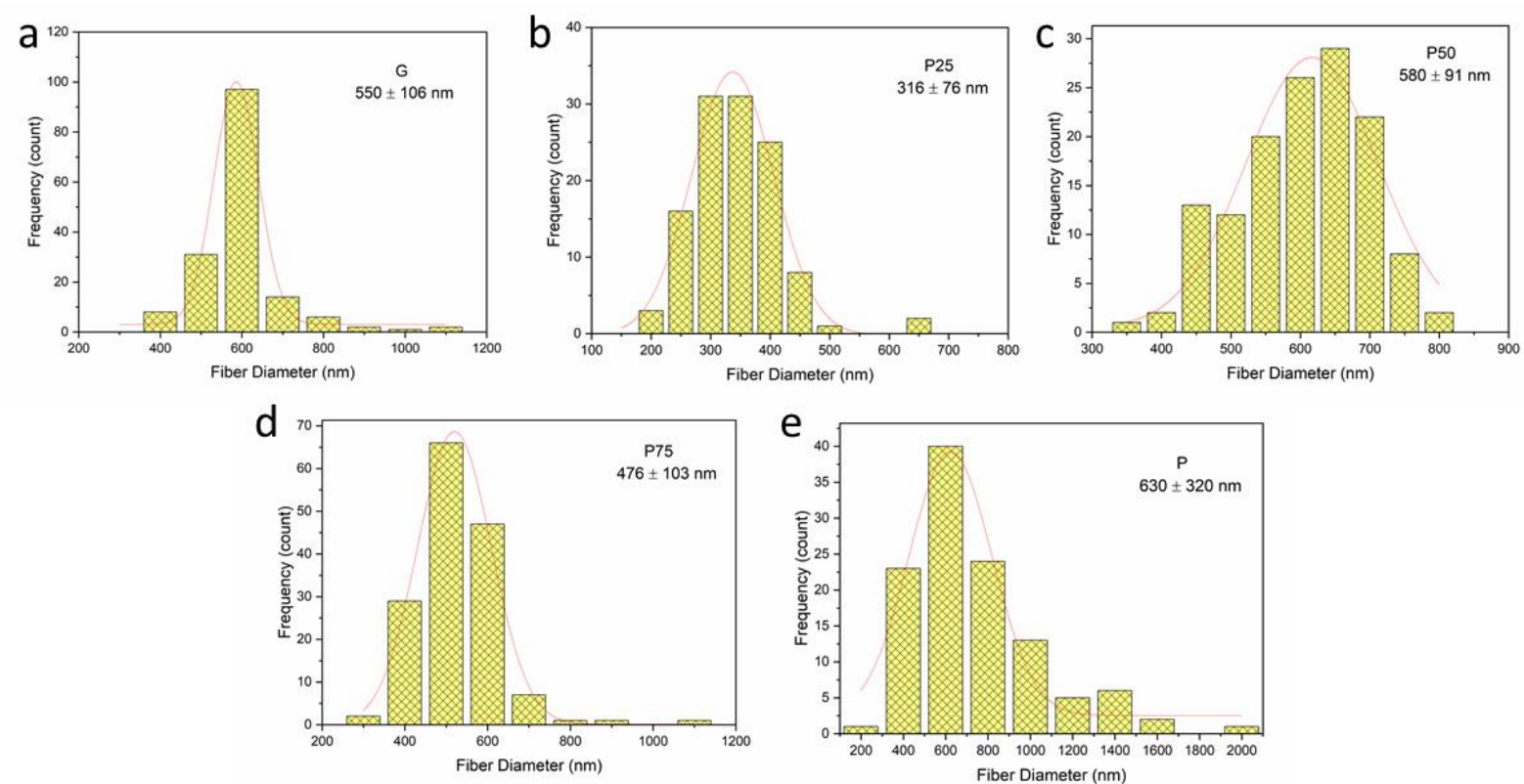

Figure S1. Diameter distribution for each crosslinked electrospun PCL/GT membranes a) c_G, b) c_P25, c) c_P50, d) c_P75, e) c_P. At least 115 randomly selected fibers in multiple micrographs were measured in ImageJ to obtain the diameter distribution. 


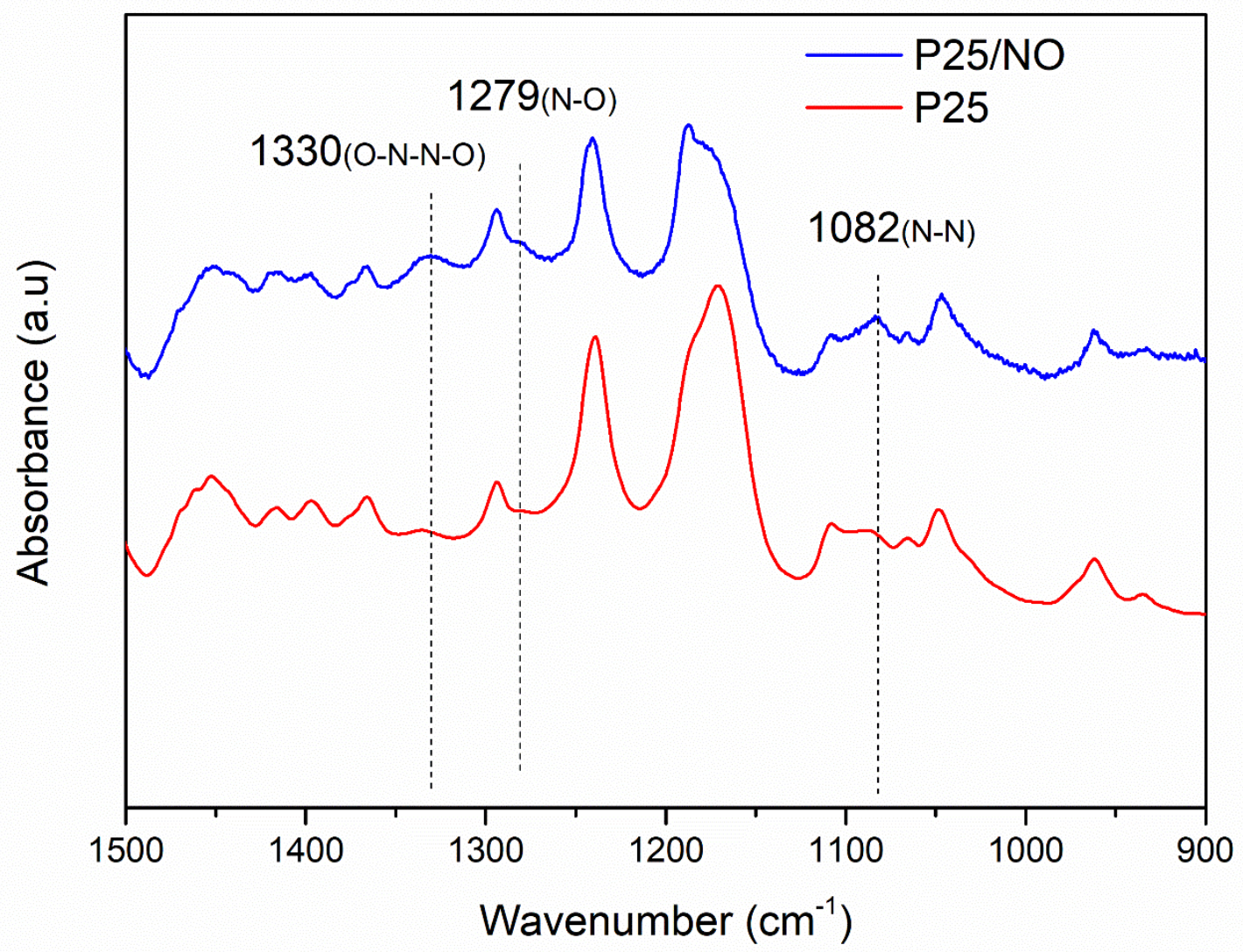

Figure S2. FTIR spectra of C_P25 and c_P25/NO membranes. Diazeniumdiolate functionalization was confirmed by the appearance of characteristic peaks at 909-1082, 1279 and 1330-1405 cm $\mathrm{cm}^{-1}$. 


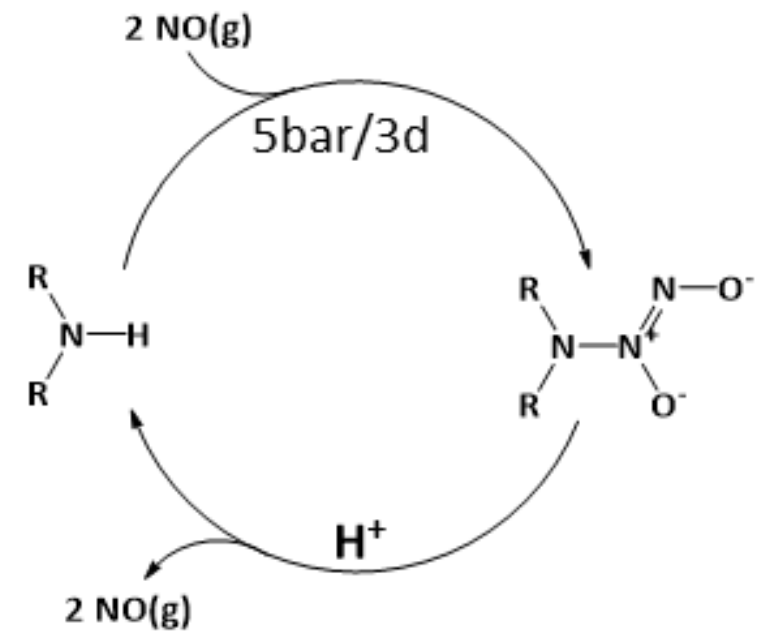

Figure S3. Mechanism of Diazeiumdiolate formation and decomposition. 


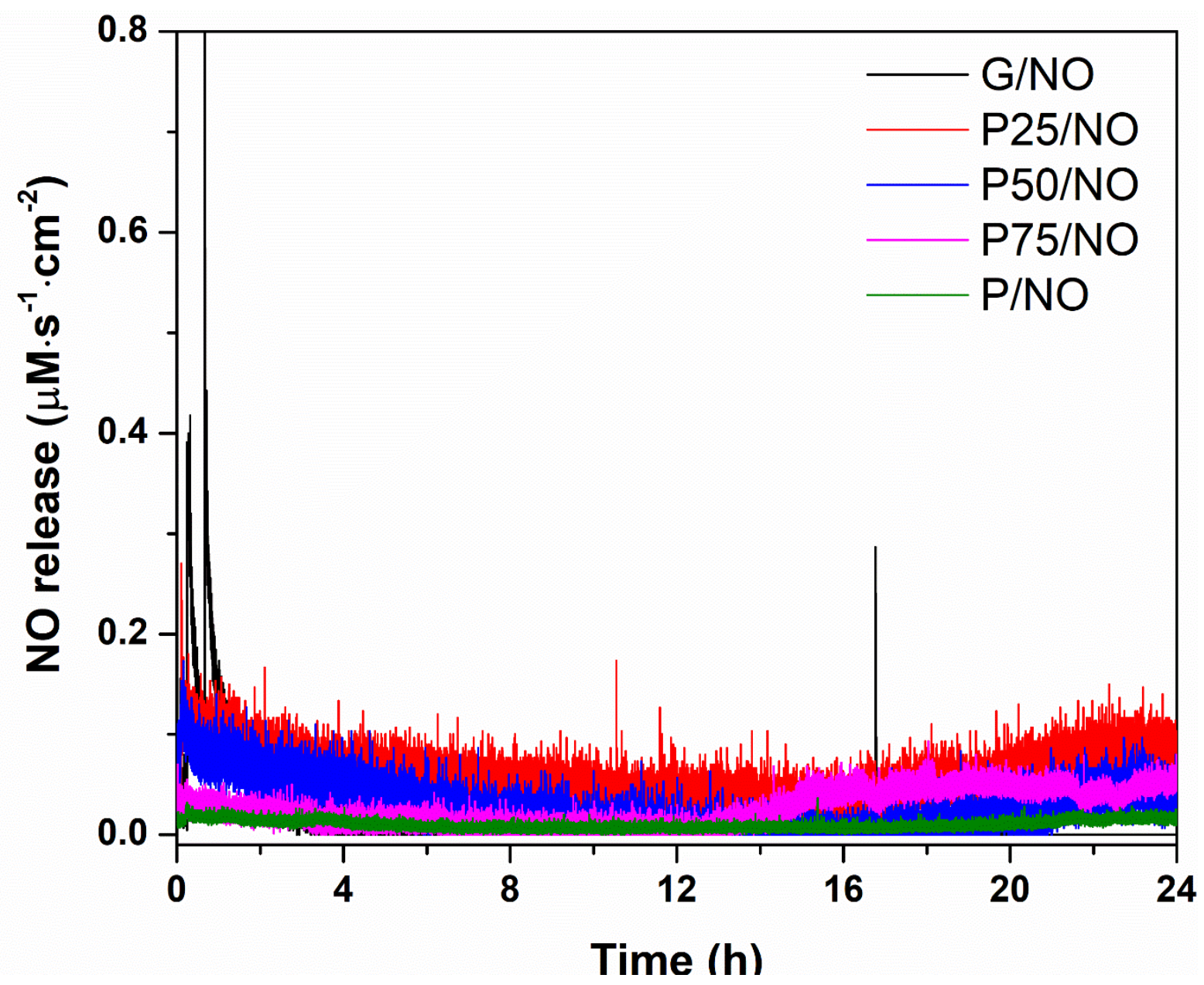

Figure S4: Chemiluminescence NO release profiles of diazeniumdiolate-functionalised membranes in cell culture medium at room temperature over time period of $24 \mathrm{~h}$. 
Table S1. NO release properties for diazeniumdiolate-functionalised membranes in cell culture medium.

\begin{tabular}{lcccc}
\hline membrane & $\begin{array}{c}\mathrm{t}[\mathrm{NO}] \\
(\mathrm{mM})\end{array}$ & $\begin{array}{c}{[\mathrm{NO}]_{\mathrm{m}}} \\
\left(\mu \mathrm{M} \cdot \mathrm{s}^{-1} \cdot \mathrm{cm}^{-2}\right)\end{array}$ & $\begin{array}{c}t_{\mathrm{m}} \\
(\mathrm{min})\end{array}$ & $\begin{array}{c}t_{\mathrm{d}} \\
(\mathrm{h})\end{array}$ \\
\hline G/NO & 2.0 & 0.8 & 38 & $20+$ \\
P25/NO & 1.8 & 0.3 & 8 & $24+$ \\
P50/NO & 1.0 & 0.1 & 11 & $24+$ \\
P75/NO & 0.5 & 0.1 & - & $24+$ \\
P/NO & 0.04 & - & - & - \\
\hline
\end{tabular}

